\title{
MURRAY HodgSON: An Appreciation From a Practicing Acoustical Consultant
}

\author{
John O'Keefe ${ }^{*}$ \\ O’Keefe Acoustics, Toronto, Ontario, Canada
}

\begin{abstract}
Résumé
Une grande partie de ce que nous savons sur le comportement du son dans les salles provient d'études effectuées dans des salles de réverbération et des salles de concert. Une géométrie architecturale peu commune au quotidien. L'auteur a rencontré Murray Hodgson pour la première fois à Cambridge lorsque le Dr. Hodgson était en train de faire ses premières études de modèles sur des usines. Du point de vue géométrique et acoustique, les usines ressemblent beaucoup plus à l'environnement bâti dans lequel nous habitons au quotidien. La géométrie d'une usine est généralement longue, large et très plate avec des éléments dispersants, généralement au sol. Murray appliqua ensuite son travail sur les usines à d'autres salles longues, basses et larges. Notre compréhension de l'acoustique des bureaux à aire ouverte, des établissements de soins de santé et, bien sûr, des salles de classe peut être attribuée à ses travaux postdoctoraux à Cambridge. Il est impressionnant que ses travaux sur l'acoustique en usine aient été transposés à une grande partie des pièces dans lesquelles nous vivons. Plus impressionnant encore fut sa capacité à traiter des questions auxquelles personne ne souhaitaient répondre. Des questions souvent posées aux consultants en acoustique et qui n'ont toujours pas de réponse, comme par exemple, celles concernant le contrôle du bruit dans les bâtiments à ventilation naturelle. Ses travaux sont devenus un fondement pour le genre naissant de l'écoconstruction.
\end{abstract}

Mots clefs : acoustique architectural, réverbération, intelligibilité de la parole, lutte contre le bruit

\begin{abstract}
So much of what we know about the behaviour of sound in rooms comes from studies in reverberation rooms and concert halls. Hardly everyday architectural geometry. The author first met Murray Hodgson in Cambridge when Dr. Hodgson was doing his early scale model studies on factories. Geometrically and acoustically, factories are much more akin to the day to day built environment that we inhabit. The geometry of a factory is typically long, wide and very flat with scattering elements, typically on the floor. Murray would go on to apply his work on factories to other long, low and wide rooms. Our understanding of the acoustics of open plan offices, health care facilities and, of course, classrooms can be traced back to his post-doctoral work in Cambridge. One is impressed how the work on factory acoustics grew to cover so much of the rooms we live in. More impressive was his ability to tackle questions that others wouldn't. Questions that acoustical consultants are often asked and really don't have an answer for yet. Noise control in naturally-ventilated buildings for example. His legacy will show this work as seminal in the nascent green building type genre.
\end{abstract}

Keywords: architectural acoustics, reverberation, speech intelligibility, noise abatement

\section{Preamble}

The following comes from the tribute session for Murray Hodgson, convened at the joint meeting of the Canadian Acoustical Association/Association Canadienne d'Acoustique and the Acoustical Society of America, held in Victoria BC on 8 November 2018. In the spirit of a testimonial to a friend, the author has suggested, and the editor and reviewers have kindly accepted, a proposal to reproduce this paper as presented. Which is to say that the following prose is more about stand up and deliver as opposed to sit down and read. This also explains its less formal conversational, first person nature, for which the author apologises for in advance.

\section{Introduction}

J'ai pensé que je pourrais commencer mes quelques mots sur notre ami Murray en Français. Parce que quand je pense à Murray j'entends l'homme criant à l'arrière de la salle lors d'une réunion de la $\mathrm{ACA}$ en criant à l'orateur : «En Français !». Donc, Murray, j'essaie d'apporter ma petite contribution, «en Français».

For our American friends, and I dare say one or two Canadians, I was just saying that one of my enduring memories of Murray was the voice from the back of a CAA General Meeting shouting to the poor fellow at the front of the room: "En Français !". And now you've just heard my feeble attempt. 


\section{Early years}

I first met Murray some 35 years ago. He'd just finished his Ph.D. [1] at Southampton's Institute of Sound and Vibration Research (ISVR) the same year that I started my Master's. That was 1983. I don't recall meeting him at ISVR though. We met in Cambridge where he was doing his post-doc work on factories and I was doing my thesis on British theatres.

There was quite a team of acousticians there, though we didn't think much of it at the time. There was Raf Orlowski, who would go on to do some important things. Mike Barron, who had already done important work and would continue to do so. Murray, doing his early scale model work on factories. And for better or (probably) worse, me!

I would go on, later, to do quite a bit of work in scale modelling. So, when I was invited to give this talk, I originally thought that I would focus on Murray's models. Something I knew a little bit about. But, after some thought and a bit of review, I realised I could talk on something I know a little bit more about - acoustical consulting.

\section{Contributions}

Because Murray's work has made a significant contribution to the tool-kit of the average work-a-day acoustician. People like many of us here today. And it all started with scale models of factories.

There was a fantastic scale modelling facility up in Cambridge, cobbled together originally by Mike Barron to study, among other things, the then new Barbican Concert Hall. Raf Orlowski tells me [2] that Mike recruited both Murray and himself. Their first grant was for the concert hall kind of work that Mike was doing. But when the 2nd and 3rd grants came along, the powers-that-be suggested: "Hey, wouldn't it be nice if you included some factories?" You know, real people! So they followed the money. Murray, of course, had done his Ph.D. on scale model factories. And that was a fortunate thing for all of us.

Here's a thought that occurred to me. Most of what we know about the behaviour of sound in a room comes from reverberation rooms and concert hall research. Neither of which share a geometry with the great bulk of the built environment. Concert halls and reverberation rooms are, proportionally, tall and often narrow. Factories, on the other hand, are often very wide with, proportionally, very low ceilings. And so are open plan offices, classrooms and hospital wards. All areas of study that Murray would go on to explore. Not to mention roadside noise barriers. The sort of thing that the average work-a-day acoustician might confront. As I have with, at the time, little guidance from the literature. Something Murray would help to take care of. There are a lot more highways and open plan offices being built these days than concert halls. There always have been and there always will be.

Our world of acoustics is, I suggest, a little too occupied with the success of its first science Reverberation Time. For any type of building that we humans might occupy, be it an office, factory, a classroom or, yes, even a concert hall... the thing that we respond to most is not reverberant decay, but Loudness. Go home and look at your stereo. The biggest knob doesn't control Reverberation. It controls Loudness!

Perhaps I should be more formal in this forum. To be more accurate, I'm referring to the Signal to Noise Ratio. Something, I note, that is documented in burgeoning field of classroom acoustics research [3,4] but is not quite as well appreciated in concert hall research.

Murray was particularly well positioned to comment and inform us on the reverberation calculations that are often found at the foundations of so much of what we do. That's because, unlike many others, he has measured all manner of rooms. Rooms that vary vastly in geometry and, in particular, the distribution of surface types. If you hang around with people like me - and many of you do - you'll find a lot of measurements in theatres and concert halls. Rooms where most of the acoustic absorption is found on a single surface. The floor. Come to think of it, when we use a reverberation room, we measure the absorption of a material laid out on the floor. Hardly the uniform distribution that either Sabine or Eyring had in mind.

So it's disconcerting that Murray should find - quite conclusively - that, although both Sabine and Eyring quite accurately predict reverberant decay, they do not do so for reverberant level [5]. This, at least in my opinion, comes from one of his more important pieces of work.

He identifies a problem that we all needed to be aware of. And now we are. Enigmatically though, he poses no solution to the problem. But there is, and there was, a solution [6]. He was aware of it. He chose not to mention it. But that's a story for another time.

Still, Murray's work gave us lowly consultants another wonderful tool for our toolkits. The knowledge of when our basic assumptions work and, just as importantly, when they don't. Both Sabine and Eyring predict reverberant decay quite reliably. Neither of them can reliably predict reverberant level [7].

\section{Scale models}

I won't say that we ever did or ever will suffer from a surfeit of concert hall scale model studies. But Murray started out with physical scale models of factories and would return to scale models when he could throughout his career. And thank goodness he did.

Thank goodness for two reasons. Almost all computer models these days are energy based, as are our Sabine and Eyring reverberation calculations. For most of us, there are no wave effects in our computer models. Parenthetically, I should add that wave based computer simulations are quickly catching up and may, someday, be useful in normal sized rooms. Most current computer models, however, are based on specular reflections, the physics of which amounts to the assumption that the reflecting surface is infinite in size and perfectly flat. No curves allowed. So, in short, if you want to believe your modern energy based computer model you have to pretend that sound is not a wave and that you are a paid up, card carrying member of the flat earth society! 
Current computer models only pretend to include diffusion effects. They do so with a physically inaccurate, mathematical sleight of hand. Diffusion is a wave effect and right now, for a large room, that can only be modelled reliably in a scale model.

One of Murray's more important studies was a quantification of the acoustic effects of fixtures on a factory floor [8]. Something he couldn't have done without physical scale models. And, I'll hasten to point out, the acoustic effects of factory floor fittings are not unlike a row of desks in a classroom or open plan office. Ever seen a reliable absorption coefficient for a desk in an open plan office, occupied or unoccupied? You may have. But I haven't.

So, that was Thank Goodness \#1. That he was working on scale models.

Thank Goodness \#2? That he was working on factories. Because, as I've mentioned, the geometry of a factory is much closer to the majority our built environment. Much closer than it might seem at first glance. As, I pointed out, it was a short step from factories to classrooms, offices and hospital wards.

\section{Sustainable acoustics}

Murray points out - quite rightly - that providing unsatisfactory acoustics in sustainable buildings is... well... unsustainable! [9] Someone is eventually going to change things. So much for sustainability.

But there is, or was, a dearth of data on green buildings as consultants like me so often found as we tried to apply our nascent science of acoustics to the real world.

Some years ago, I did a green office building for Manitoba Hydro in Winnipeg. A city known affectionately to the Canadians in this room as "Winterpeg". Situated at the centre of the continent, it suffers a continental climate of extremes. Freezing cold in the winter and boiling hot in the summer. If ever there was a challenge for sustainable design, this was the place. The building more than met those challenges and won a number of awards. None of them, I'm sure you've guessed, were for the acoustics!

Murray was one of the first to publish cold hard facts about the acoustics of green buildings [10,11]. Unfortunately for me, that was in the early $2,000 \mathrm{~s}$, a few years after we had completed the design. With calculations that I don't mind telling you were, at the time, no more than acoustical stabs in the dark. It's nice to know that we now have documented data to verify what we're trying to predict. And Murray, more than any other I might suggest, got that ball rolling.

\section{Multi-disciplinary}

Murray's work so often crossed so many disciplines. Factory workers, architects, school teachers and so many more. Murray worked with them all.

Having recently donned a pair of hearing aids, [12] I've taken a latter day interest in audiology. My wife, who actually is an audiologist, never tires of telling me that acousticians really don't know all that much about hearing. But that didn't faze our friend Murray.
Get this for a multi-disciplinary study: ship building, workers' health and safety and the very wide chasm between acoustics and audiology. And believe me, there is a chasm. I've lived the last 35 years of my life learning how just much I don't know about audiology! I'm speaking, of course, of Murray's work with our friend Chantal LaRoche [13], oh about fifteen years ago.

The resulting papers, many of which were presented here in Victoria at our meeting in 1999 were published later in Canadian Acoustics/Acoustique Canadienne [14]. These papers are a tour de force in the application of multidisciplinary research.

\section{Editor}

Finally, I would be remiss if I did not mention Murray's time as our editor of Canadian Acoustics/Acoustique Canadienne. From 1990 to 1998.

He said that one of his proudest achievements in that office was the publication the late Raymond Hétu's controversial comments on Occupational Hearing [15]. Which wasn't easy. The illustrious likes of Edgar Shaw, for example, refused to review it. Murray was even threatened with legal action. But you didn't mess with our Murray, especially when he cared about something. Thanks to his persistence, the debate that Hétu initiated was given a voice.

\section{Conclusion}

Factories, offices, classrooms, hospitals and, yes, even ships on the ocean. He's done them all and done them well.

He enjoyed the admiration and affection of his students. That affection was well earned. I was told last night that he was still helping his students from his hospital bed.

$\mathrm{He}$ commanded the respect of all of us in the Canadian Acoustical Association and, of course, acousticians throughout the world. And I thank so many of you for coming here today. He died too soon. But few of us will soon forget him.

In our little corner of science called acoustics, the description of our built environment is a better place for the work of our friend Murray Hodgson. I can think of no better tribute for the work or for the man.

$\mathrm{Au}$ revoir mon ami.

\section{References}

[1] Hodgson, M.R., Theoretical and physical models as tools for the prediction of factory sound fields, Ph.D. Dissertation, University of Southampton (1983).

[2] Orlowski, Private communication, Hamburg, 5 October 2018.

[3] Prodi, N., Visentin, C., and Feletti, A., On the perception of speech in primary school classrooms: Ranking of noise interference and of age. influence, J. Acoust. Soc. Am. 133, 255268. (2013).

[4] Brill, L.C., Smith, K., Wang, L., Building a Sound Future for Students: Considering the Acoustics in Occupied Active Classrooms, Acoustics Today 14(3), 14-22 (Fall 2018). 
[5] Hodgson, M.R., Experimental evaluation of the accuracy of the Sabine and Eyring theories in the case of non-low surface absorption, J. Acoust. Soc. Am. 94(2), 835-840 (1993).

[6] Barron, M., Lee, L.J., Energy relations in concert auditoriums. Part I, J. Acoust. Soc. Am. 84, 618-628 (1988).

[7] Hodgson, M.R., When Is Diffuse-Field Theory Accurate?, Canadian Acoustics/Acoustique Canadienne, 22(3) 41-42 (1994)

[8] Hodgson, M.R., Improved methods for estimating fitting density in industrial workrooms, J. Sound \& Vibration 218(3):463479 (December 1998).

[9] Hodgson, M., Evaluation and Control of Acoustical Environments in 'Green' (Sustainable) Office Buildings, Canadian Acoustics/Acoustique Canadienne, 39(1) 11-21 (2011)

[10] Richter, M., Hyde, R. and Hodgson, M. (2006). "Acoustical lessons from four 'green' buildings", Journal of the Acoustical Society of America 120(5, Pt. 2) 3184.
[11] Hodgson, M.R., Evaluation and Control of Acoustical Environments in 'Green' (Sustainable) Office Buildings, Canadian Acoustics/Acoustique Canadienne, 39(1), 11-21 (2011).

[12] O'Keefe, J., The Acoustician Who Has To Wear Hearing Aids, Proc. IOA, Vol. 40. Pt. 3., pp. 487-492, 2018.

[13] Hodgson, M.R., Forshaw, S., Ritmiller, L., Laroche, C., Characterizing Ship Acoustical Environments for Speech Communication, Canadian Acoustics/Acoustique Canadienne 27(3), 110-111 (1999) .

[14] Canadian Acoustics/Acoustique Canadienne, Volume 27, No. 3 (1999).

[15] Bradley, J.S., Ramakrishnan, R., History of Canadian Acoustics, Canadian Acoustics/Acoustique Canadienne, 41(1), 3-4 (2013).

\section{Sound and Vibration Instrumentation Scantek, Inc.}

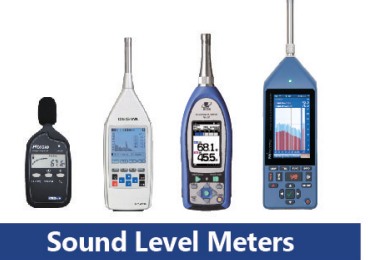

Selection of sound level meters for simple noise level measurements or advanced acoustical analysis
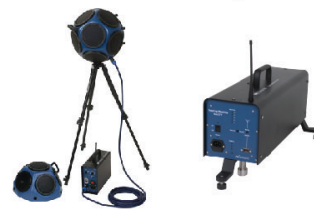

Building Acoustics

Systems for airborne sound transmission, impact insulation, STIPA, reverberation and other room acoustics measurements

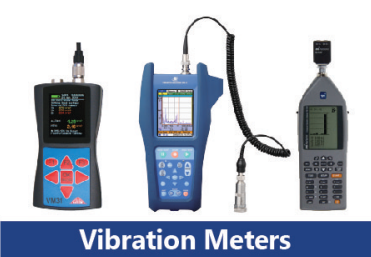

Vibration meters for measuring overall vibration levels, simple to advanced FFT analysis and human exposure to vibration

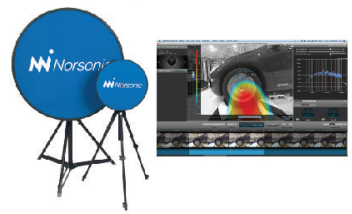

Sound Localization

Near-field or far-field sound localization and identification using Norsonic's state of the art acoustic camera

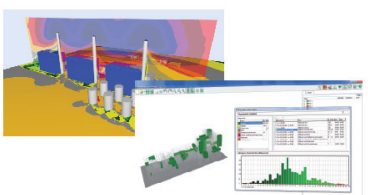

Prediction Software

Software for prediction of environmental noise, building insulation and room acoustics using the latest standards

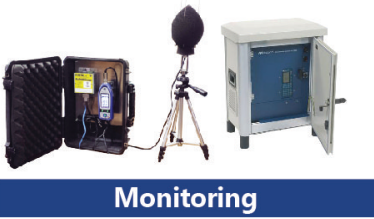

Temporary or permanent remote monitoring of noise or vibration levels with notifications of exceeded limits 